\title{
Efficacy and safety of oral mifepristone for cervical priming and induction of labor in term pregnancy
}

\author{
Abhilasha Gupta1, Aruna Verma ${ }^{1 *}$, Iti Madan',2, Monika Kashyap ${ }^{3}$ \\ ${ }^{1}$ Department of Obstetrics and Gynecology, LLRM Medical College, Meerut, Uttar Pradesh, India \\ ${ }^{2}$ Senior Resident, ESIC Medical College and Hospital, Faridabad, India \\ ${ }^{3}$ Department of Obstetrics and Gynecology, MSYMC, Kharkhauda, Uttar Pradesh, India \\ Received: 01 May 2018 \\ Accepted: 29 May 2018 \\ *Correspondence: \\ Dr. Aruna Verma, \\ E-mail: arunaverma36@gmail.com \\ Copyright: ( $)$ the author(s), publisher and licensee Medip Academy. This is an open-access article distributed under \\ the terms of the Creative Commons Attribution Non-Commercial License, which permits unrestricted non-commercial \\ use, distribution, and reproduction in any medium, provided the original work is properly cited.
}

\begin{abstract}
Background: The objectives of the study was to assess the efficacy of mifepristone in priming the cervix/inducing labor over next $96 \mathrm{hrs}$ in term pregnancy.

Methods: In this single blind randomized controlled trial 200 women with term pregnancy beyond 39 weeks and Bishop' score $<6$ were randomly allocated into two groups. Tab Mifepristone $400 \mathrm{mg}$ orally was given to women in study group $(n=100)$ and no intervention in control group $(n=100)$. On follow up one case was lost in control group. All women were observed for change in the bishop's score or onset of labor in next 96 hrs. If Bishop's score was $<6$, the choice of induction was left on the clinician/patient.

Results: Mean induction to delivery interval, duration of active phase and improved Bishop score were 79.35 \pm 53.43 $\mathrm{hr}, 2.47 \pm 1.23 \mathrm{hr}, 6.68 \pm 1.69$ for study group versus $148 \pm 65.66 \mathrm{hr}, 3.09 \pm 1.45 \mathrm{hr}, 5.8 \pm 2.15$ for control group ( $\mathrm{p}$ value is $<0.001)$ respectively. Seventy one $(71 \%)$ women in study group and 39 (39.3\%) women in control group delivered vaginally within $96 \mathrm{hrs}$ without any need of augmentation. There were $9(9 \%)$ caesareans in study group and 24 $(24.2 \%)$ caesareans in control group but no instrumental delivery in both groups. There was no statistically difference in perinatal outcomes between two groups.

Conclusions: Mifepristone is an effective drug for cervical ripening and initiation of labor when given in term pregnancy beyond 39 weeks with poor Bishop's score $(<6)$ and appearing to reduce need for other agent for augmentation of labor.
\end{abstract}

Keywords: Bishop's score, Cervical priming, Induction of labor, Mifepristone

\section{INTRODUCTION}

Induction of labor is one of the important tools in an obstetrician's armamentarium as he/she can intervene and induce labor as may be indicated for maternal or fetal interest or both. In the current obstetric practice, induction is performed for obstetric or medical indications or at times for woman's convenience. The availability of new oxytocics and induction techniques which are more effective as well as more predictable have significantly modified our traditionally conservative attitude towards induction of labor, which was once regarded as 'meddlesome midwifery'. The search for newer and safer agents is still ongoing. Criteria for term gestation should be met, if elective induction is undertaken. These criteria include ultrasound measurement at less than 20 weeks supporting a gestational age of 39 weeks or greater, documentation of 30 weeks of fetal heart tones by Doppler ultrasonography, or passage of 36 weeks since a positive serum or urine human chorionic gonadotropin pregnancy test. $^{1}$ 
A workgroup including representatives from the American College of Obstetricians (ACOG), the Society For Maternal Fetal Medicine (SMFM) and Eunice Kennedy Shriver National Institute of Child health and Human development (NICHO) have recommended more specifically categorizing deliveries as

- Preterm- $<37$ weeks

- Early term- $37 \% \frac{1}{7}-38 \% / 7$ weeks

- Term- 39\% $-40 \% / 7$ weeks

- Late term- $41 \% / 7-416 / 7$ weeks

- Post term- $>42$ weeks ${ }^{2}$

Data had shown that the lowest incidence of perinatal morbidity and mortality occurs around 39-40 weeks. ${ }^{3}$ As perinatal morbidity and mortality rates are higher during the early-term period $\left(37^{0}-38^{6}\right)$ compared with those delivered at $\geq 39$ weeks, the American College of Obstetricians and Gynecologists (ACOG) and the Society for Maternal-Fetal Medicine (SMFM) have recommended against non-medically indicated deliveries before 39 weeks. $^{4}$ Instead, perinatal mortality starts to increase again with late term $\left(41^{0}-41^{6}\right.$ weeks) and post term ( $\geq 42$ weeks) pregnancies. Therefore, they advocated induction of even uncomplicated singleton gestations once they reach full-term $\left(39^{0}-40^{6}\right.$ weeks $) .^{5}$

As a fall in the level of progesterone is considered one of the important events in the onset of spontaneous labor, the antiprogesterone agent mifepristone was used in several trials to induce labor at term. Mifepristone (RU 486) is a 19-norsteroid that binds strongly to progesterone receptor and inhibits the activity of progesterone at cellular level with potent antiprogestogenic, antiglucocorticoid and a weak antiandrogenic actions, has minimal effects on uterine contractility as it ripens the cervix, making it an option for use in induction and enhance the rates of spontaneous labor, with no apparent maternal or neonatal side effects. ${ }^{6}$

In late pregnancy, the uterus is sensitized by mifepristone to prostaglandins and promotes cervical dilatation which often induces labor. Various studies conducted on induction of labor in live term pregnancies with mifepristone in doses of 200-400 $\mathrm{mg}$ have shown to improve cervical ripening and rates of spontaneous labor with no apparent maternal or fetal side effects. It is characterized by rapid absorption and long half life of 24$30 \mathrm{hrs}^{7}$. The sequential use of mifepristone and a prostaglandin has been extensively researched for termination of pregnancy in all trimesters and in inducing labor in cases of intrauterine deaths. ${ }^{8,9}$

The earliest studies on the use of mifepristone for induction of labor were done by Frydman and colleagues in 1990's. Also it was reported that mifepristone is better than a placebo in ripening the cervix and there is evidence of a possible reduction in the incidence of cesarean section rates following mifepristone treatment.
In this context, the present study is an attempt to evaluate the efficacy and safety of mifepristone in induction of labor in live term pregnancy with poor bishop's score and the management of post-dated pregnancy begins before it actually becomes so.

\section{METHODS}

\section{Design, duration and sample size}

This single blinded randomized controlled clinical trial of sample size 200 was conducted in LLRM Medical College, Meerut, from July 2015 to June 2016 with approval from ethical committee.

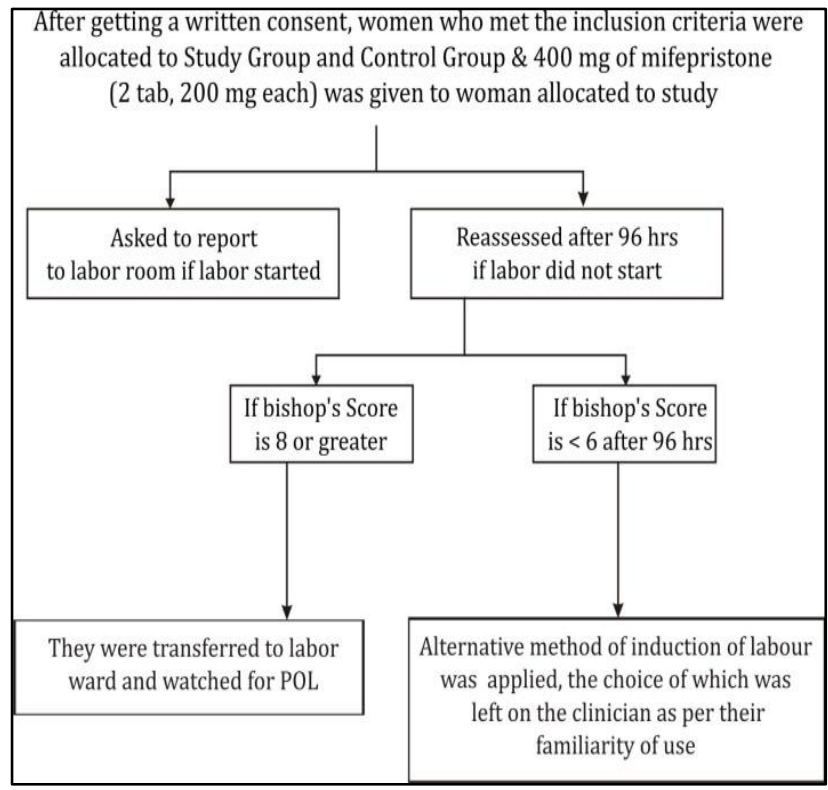

Figure 1: Study design.

\section{Inclusion criteria}

- Women with singleton pregnancy of 39-40 wks duration (criteria include ultrasound measurement at less than 20 weeks supporting a gestational age of 39 weeks or greater, documentation of 30 weeks of fetal heart tones by Doppler ultrasonography, or passage of 36 weeks since a positive serum or urine human chorionic gonadotropin pregnancy test) with cephalic presentation with no contraindication for vaginal delivery. ${ }^{1}$

- Modified cervical Bishop's score $<6$ prior to induction.

\section{Exclusion criteria}

- Women not giving consent for study.

- $\quad$ Parity $>5$

- Previously scarred uterus: Cesarean, Myomectomy, other surgical scar.

- Known hypersensitivity to prostaglandins or mifepristone. 
- $\quad$ Significant cephalopelvic disproportion as assessed by abdominovaginal method.

- Medical conditions like diabetes, cardiac disease, impaired renal \& hepatic function.
- Others including antepartum hemorrhage, severe oligohydroamnios (AFI<5), non-reassuring NST (non stress test).

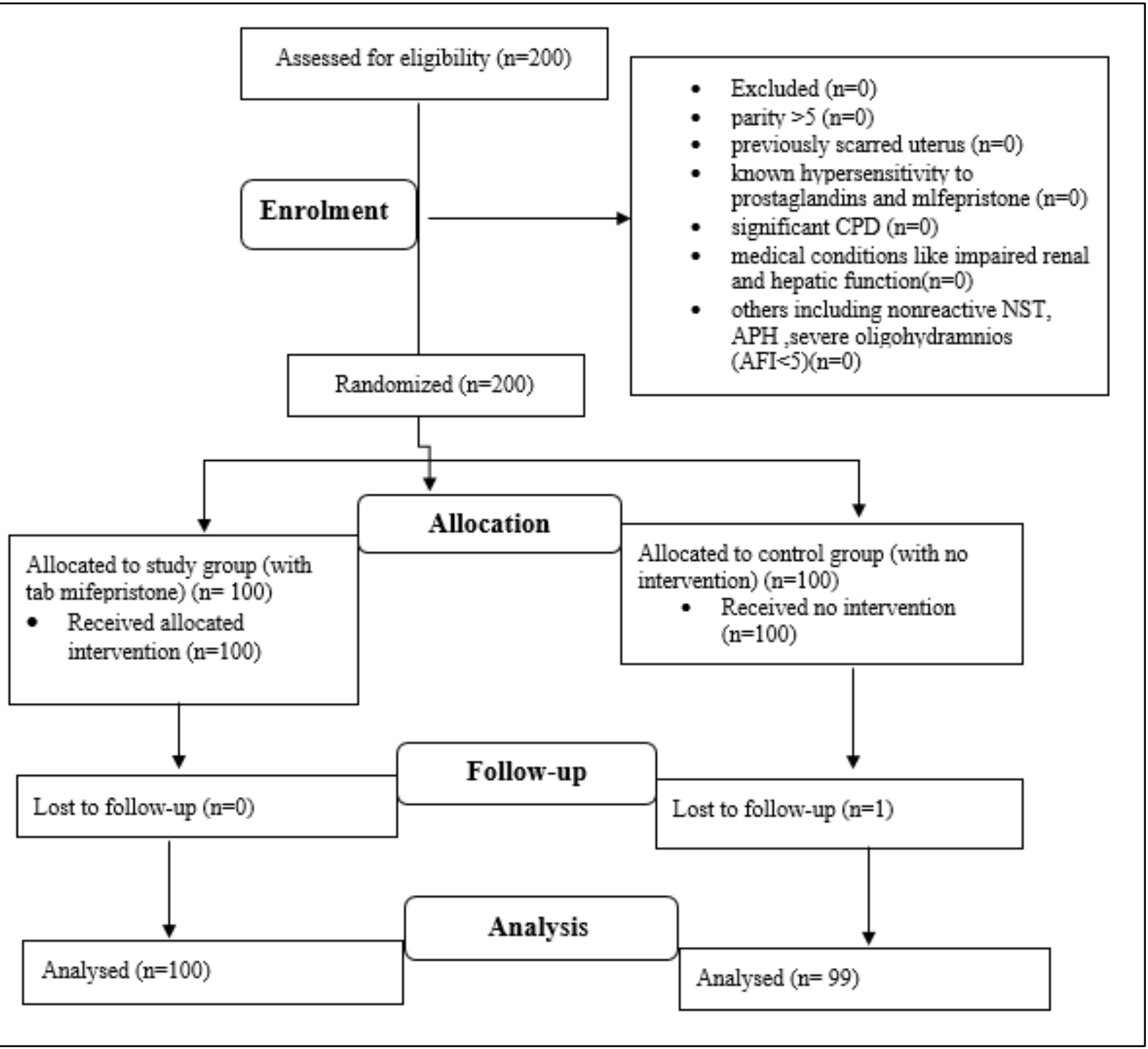

Figure 2: CONSORT flow diagram.

After having CBC, blood group, RBS, urine $\mathrm{R} / \mathrm{M}$, virology and ultrasonography of all women, they were randomly allocated to 1 of 2 groups in a $1: 1$ ratio by block randomization with computer generated randomly permuted blocks of size 8 .

The numbers were written on small slips and placed in sequentially numbered opaque sealed envelopes (SNOSE METHOD). The subject were randomized into two groups, study and control group.

\section{RESULTS}

Table 1 shows both groups were comparable regarding maternal age, gestational age, geographical difference, occupation and parity.

Table 2, 3 and 4 show maternal outcome. The mean improvement in Bishop's score after 96 hrs was $6.45 \pm 1.54$ in study group and 4.06 \pm 1.69 in control group and was statistically significant $(\mathrm{p}<0.05)$. However, change in bishop score after 96 hours was $9.35 \pm 1.55$ in 
study group and $8.31 \pm 1.8$ in control group which was also statistically significant $(\mathrm{p}<0.05)$. Cervical ripening was seen in $88 \%$ women in study group and in $38.3 \%$ in control group at the end of $96 \mathrm{hrs,} \mathrm{which} \mathrm{was} \mathrm{statistically}$ significant $(\mathrm{p}<0.05)$.

Table 1: Distribution in terms of demographic profile, age, gestational age and parity.

\begin{tabular}{|lllll|}
\hline Variables & & Study N (100) & Control N (99) & P value \\
\hline Mean age (mean \pm SD) & $24.23 \pm 2.62$ & $24.18 \pm 3.02$ & 0.91 \\
\hline \multicolumn{2}{|l}{ Mean gestational age (mean \pm SD) } & $39.34 \pm 0.32$ & $39.41 \pm 0.35$ & 0.11 \\
\hline $\begin{array}{l}\text { Geographical } \\
\text { difference }\end{array}$ & Rural n (\%) & $65(65)$ & $62(62.6)$ & 0.76 \\
\hline \multirow{2}{*}{ Occupation } & Urban n (\%) & $35(35)$ & $37(37.3)$ & 0.09 \\
\hline \multirow{2}{*}{ Parity } & Housewife n & 90 & 95 & 0.031 \\
\cline { 2 - 5 } & Working n & 10 & $52(52.5)$ & \multirow{2}{*}{0} \\
\hline
\end{tabular}

Table 2: Distribution of women depending on change in Bishop's score.

\begin{tabular}{|llll|}
\hline Variables & Study N (100) & Control N (99) & P value \\
\hline Mean Bishop's score at 0 h (mean \pm SD) q1 & $2.79 \pm 1.29$ & $2.77 \pm 1.16$ & 0.90 \\
\hline Mean Bishop's score after 96 h (mean \pm SD) q2 & $9.35 \pm 1.55$ & $8.31 \pm 1.8$ & 0.00 \\
\hline $\begin{array}{l}\text { Improvement in Bishop's score after 96 h (mean } \pm \text { SD) } \\
\text { q3=q2-q1 }\end{array}$ & $6.45 \pm 1.54$ & $4.06 \pm 1.69$ & 0.00 \\
\hline Cervical ripening (Bishop's score $\geq 6$ ) at the end of 96 hrs & $88(88 \%)$ & $38(38.3 \%)$ & $<0.05$ \\
\hline
\end{tabular}

Table 3: Distribution of women according to mode of termination of pregnancy.

\begin{tabular}{|c|c|c|c|}
\hline Variables & Study n (\%) & Control n (\%) & P value \\
\hline $\begin{array}{l}\text { Mean enrollment to delivery } \\
\text { interval in hrs (mean } \pm \text { SD) }\end{array}$ & $79.55 \pm 43.43$ & $135.58 \pm 64.11$ & $<0.05$ \\
\hline $\begin{array}{l}\text { Mean duration of active phase of } \\
\text { labor in hrs }(\text { mean } \pm \text { SD) }\end{array}$ & $2.86 \pm 1.25$ & $4.01 \pm 1.68$ & $<0.05$ \\
\hline \multicolumn{4}{|l|}{ Mode of delivery } \\
\hline Vaginal delivery within 96 hrs & $77(77 \%)$ & $24(24.2 \%)$ & \multirow{2}{*}{$<0.05$} \\
\hline Vaginal delivery after $96 \mathrm{hrs}$ & $14(14 \%)$ & $51(51.5 \%)$ & \\
\hline Caesarean delivery & $9(9 \%)$ & $24(24.2 \%)$ & \\
\hline Assisted delivery & 0 & 0 & \\
\hline
\end{tabular}

Table 4: Distribution according to need for induction in both groups.

\begin{tabular}{|c|c|c|c|}
\hline Variables & Study N (100) & Control N (99) & P value \\
\hline Spontaneous delivery & 71 & 39 & \multirow{5}{*}{$<0.05$} \\
\hline Oxytocin & 20 & 30 & \\
\hline Misoprostol & 3 & 21 & \\
\hline Oxytocin+misoprostol & 5 & 8 & \\
\hline Dinoprostone gel & 1 & 2 & \\
\hline $\begin{array}{l}\text { Mean dose of misoprostol } \\
\text { required in mcg (mean } \pm \text { SD) }\end{array}$ & $46 \pm 16.02$ & $67.24 \pm 25.97$ & 0.04 \\
\hline
\end{tabular}

The proportion of vaginal deliveries in study group was $91 \%$ and in control group was $75.7 \%$. More number of women in study group delivered per vaginum i.e. $77 \%$ than in control group $24.2 \%$ within $96 \mathrm{hrs}$. $\mathrm{P}$ value $<0.5$ states that this difference was statistically significant.
There was lesser rate of caesarean section in study group i.e. $9 \%$ than control group which was $24.2 \%$.

Mean enrolment to delivery interval was $79.55 \pm 43.43 \mathrm{hrs}$ in study group and $135.58 \pm 64.11 \mathrm{hrs}$ in control group which came out to be significant on statistical analysis by 
student $\mathrm{t}$ - test as $\mathrm{p}$ value was $<0.05$. Statistically significant reduced mean duration of active phase of labor was seen in study group which was $2.86 \pm 1.25 \mathrm{hrs}$ but in control group it was $4.01 \pm 1.68 \mathrm{hrs}$ ( $\mathrm{p}$ value was $<0.05)$.

Table 5: Induced labor outcome.

\begin{tabular}{|llllll|}
\hline Variables & Study $(\mathrm{n}=29)$ & $\%$ & Control $(\mathrm{n}=61)$ & $\%$ & P value \\
\hline Vaginal delivery & 20 & $69 \%$ & 37 & $61 \%$ & $<0.05$ \\
\hline Caesarean section & 9 & $31 \%$ & 24 & $39 \%$ & \\
\hline
\end{tabular}

Table 6: Distribution of adverse neonatal outcome in both groups.

\begin{tabular}{|c|c|c|c|}
\hline Variables & Study N (100) & Control N (99) & P value \\
\hline \multicolumn{4}{|l|}{ Evidence of fetal distress } \\
\hline Irregular FHS & 6 & 23 & \multirow{2}{*}{0.88} \\
\hline Meconium stained liquor & 8 & 28 & \\
\hline \multicolumn{4}{|l|}{ Need for resuscitation } \\
\hline Positive pressure ventilation & 5 & 21 & \multirow{2}{*}{0.33} \\
\hline Chest compression & 0 & 4 & \\
\hline Jaundice & 0 & 0 & \multirow{6}{*}{0.13} \\
\hline Respiratory distress & 2 & 4 & \\
\hline Birth asphyxia & 2 & 3 & \\
\hline Perinatal death & 0 & 2 & \\
\hline Septicemia & 1 & 3 & \\
\hline Neonatal hypoglycemia & 0 & 0 & \\
\hline NICU admission & 5 & 16 & 0.004 \\
\hline
\end{tabular}

Table 5 show efficacy and safety of drug regimen. Need for induction of labor was more in control group as 61 women were induced with other method in control group whereas 29 women in case group. 69 out of 100 women in study group were spontaneously delivered vaginally as compared to 31 out of 99 women in control group.

Mean dose of misoprostol required for augmentation was higher in control group $67.24 \pm 25.97 \mathrm{mcg}$ as compared to study group $46 \pm 16.02 \mathrm{mcg}$ and $\mathrm{p}$ value was 0.04 which showed statistically significant difference. Majority of the population did not have any complication.

In study group maternal complication were seen in the form of postpartum haemorrhage, tachysystole, uterine hyperstimulation and maternal exhaustion, which were comparable to control group as $\mathrm{p}$ value was 0.05 .

Table 6 shows that the neonatal outcome is same in all the respects in both groups and there is no statistically significant difference between the two groups. Moreover, there were two perinatal deaths, one was still birth and one expired due to birth asphyxia on day 2 in NICU.

Adverse neonatal outcome (fetal distress and meconium stained liquor) were more in control group as compared to study group specifically in those cases which were induced or augmented with misoprostol or oxytocin with greater relative risk. One case in control group was lost to follow up.

In control group, greater number of neonates admitted in NICU, some of them on day 2 or 3 due to meconium aspiration, respiratory distress, septicemia and birth asphyxia, which was statistically significant on statistical analysis $(\mathrm{p}=0.004)$.

\section{DISCUSSION}

Research continues to invent and modify doses of different drugs for induction of labor. The female sex hormone, progesterone stops the uterine contraction during pregnancy. Drugs such as mifepristone have been used to stop the action of this hormone, either to induce labor or to allow the pregnancy to be terminated.

In the present study, we opted for $400 \mathrm{mg}$ tab mifepristone. Byrne demonstrated that mifepristone exposure and induced labor were associated with increase in cortisol levels and significant elevation in cortisol levels was observed within $18 \mathrm{hrs}$ of exposure to mifepristone. ${ }^{10}$

Hapangama reported that there is insufficient evidence to support a particular dose, but a single dose of $200 \mathrm{mg}$ 
mifepristone appeared to be the lowest effective dose for cervical ripening (RR $2.13,95 \%$ CI 1.15 to 3.97 ). ${ }^{12}$

In our study statistically significant improvement was observed in mean bishop's score in study group at the end of $96 \mathrm{hrs}$. This improvement in score indirectly indicates the withdrawal of progesterone support.

Wing et al demonstrated more women had favourable bishop's score after 24 hrs of mifepristone than placebo though the difference was not found to be statistically significant. ${ }^{13}$ Athawale et al and Fathima et al also noted the significant change in bishop's score with the use of oral mifepristone. ${ }^{14,15}$

We found statistically significant decrease in the requirement of misoprostol with prior use of mifepristone. Our results were consistent with the literature that shows decreased prostaglandin requirements when mifepristone is given either for second trimester pregnancy termination or term induction. Wing et al also reported the reduced need of prostaglandin/oxytocin in mifepristone group. ${ }^{13}$

Frydmann et al also reported 3\% women went into labor within $24 \mathrm{hrs}$ of ingestion of mifepristone. Hapangama reported that mifepristone-treated women were more likely to be in labor or to have favourable cervix at $48 \mathrm{hrs}$ (risk ratio (RR) $2.41,95 \%$ CI 1.70-3.42), and this effect persists at $96 \mathrm{hrs}$ (RR 3.40, 95\% CI 1.96-5.92). ${ }^{8}$

In the present study, 71 women in study group went in labor and delivered vaginally without any need of misoprostol within 96 hrs of ingestion of mifepristone. This was found to be statistically significant and may be co-related that women with prolonged pregnancy may have more chances to go in labor earlier.

In the present study, $71(71 \%)$ women in study group delivered vaginally within 96 hrs. Similar results were reported by Wing et al. ${ }^{16}$ In the present study, there were $9(9 \%)$ caesareans and no instrumental delivery in study group. More spontaneous vaginal deliveries and less incidence of caesarean and less instrumental deliveries were noted by Fathima et al. ${ }^{15}$

Dharani $\mathrm{H}$ reported that mifepristone-treared women were less likely to undergo caesarean section or failure of induction [RR $0.74,95 \%$ CI 0.60 to 0.92 ], [RR $0.40,95 \%$ CI 0.20 to 0.80$].{ }^{12}$ There was less likely need of augmentation with oxytocin (RR 0.80 , 95\% CI 0.66 to 0.97). The rate of successful induction in our study was $77 \%$ as 77 women in study group delivered vaginally within $96 \mathrm{hrs}$ and $9 \%$ delivered by caesarean section ( $p<0.05)$. These findings were more close to the study of Wing. ${ }^{16}$ Dharani $\mathrm{H}$ reported that abnormal fetal heart rate patterns were not common (RR 1.85 , 95\% CI 1.17 to 2.93) and there was no difference in other neonatal outcome. Similar findings were observed in present study. ${ }^{12}$
Funding: No funding sources

Conflict of interest: None declared

Ethical approval: The study was approved by the Institutional Ethics Committee

\section{REFERENCES}

1. Chervenak FA. Current progress in obstretics and gynaecology. 2015

2. Spong CY. Defining Term pregnancy: recommendations from the Defining "term" pregnancy Workgroup. JAMA. 2013;309:2445-6.

3. Reddy UM, Ko CM, Raju TN, Willinger $M$. Delivery indications at late preterm gestations and infant mortality rates in The United States. Pediatrics. 2009; 124:234-40.

4. ACOG Committee Opinion. Nonmedically indicated early-term deliveries. Committee opinion. Number 561. Obstet Gynecol. 2013; 121.

5. Cole RA, Howie PW, Macnaughton MC. Elective induction of labour. A randomized 265 prospective trial. Lancet. 1975;1:767-70.

6. Newhall EP, Winikof B. Abortion with mifepristone and misoprostol: regimens, efficacy, acceptability and future directions. Am J Obstet Gynecol. 2000; $182: 44-53$.

7. Heikinheimo O, Kekkonen R, Lähteenmäki P. The pharmacokinetics of mifepristone in humans reveal insights into differential mechanisms of antiprogestin action. Contraception. 2003;68(6):421-6.

8. Frydman R, Lelaidier C, Baton-Saint-Mleux C, Fernandez H, Vial M, Bourget $\mathrm{P}$ et al. Labour induction in women at term with mifepristone: a double blind controlled trial. Obstet Gynecol. 1992;80:972-5.

9. Gemzell-Danielsson K, Lalitkumar S. Second trimester medical abortion with mifepristonemisoprostol and misoprostol alone: a review of methods and management. Reproductive Health Matters. 2008;16(31):162-1726.

10. Byrne JD. Term pregnancy. J Perinatol. 2004;24:416-20.

11. ACOG Committee Opinion no.579: Definition of term pregnancy. Obset Gynecol. 2013;122:1139-40.

12. Dharani H, James PN. Mifepristone for induction of labour (review). Chochrane Database Syst Rev. 2009; 3, Art. No. CD002865.

13. Wing DA, Fassett Michael J, Mishell Daniel R. Mifepristone for preinduction cervical ripening beyond 41 weeks' gestation: a randomized controlled trial. Obstet Gynecol. 2000;96:543-8.

14. Athawale R, Acharya N, Samal S. Effect of mifepristone in cervical ripening for induction of labour. Int J Reprod Contracept Obstet Gynecol. 2013;2(1):35-8.

15. Fathima S, Nayak SR, Rao B. Mifepristone in induction of labour at term. Int $\mathbf{J}$ of Pham Biomed Res. 2013;4(3):164-6.

16. Wing D, Guberman C, Fassett M. A comparison of oral mifepristone to intravenous oxytocin for pre- 
induction cervical ripening and labour induction in women with pre-labour rupture of membranes beyond 36 weeks gestation. American J Obstetrics Gynecol. 2003;189(6):204.

17. Wing D, Guberman C, Fassett M. A Randomized comparison of oral mifepristone to intravenous oxytocin for labor induction in women with prelabor rupture of membranes beyond 36 weeks' gestation.
American
$\mathrm{J}$
Obstetricians
Gynaecologists.

2005;192:445-51.

Cite this article as: Gupta A, Verma A, Madan I, Kashyap M. Efficacy and safety of oral mifepristone for cervical priming and induction of labor in term pregnancy. Int J Reprod Contracept Obstet Gynecol 2018;7:2766-72. 